\title{
The Influence of Different Length Aluminum Foam Filling on Mechanical Behavior of a Square Thin-Walled Column
}

\author{
Michał Rogala ${ }^{1, * \mathbb{D}}$, Mirosław Ferdynus ${ }^{1} \mathbb{D}$, Katarzyna Gawdzińska ${ }^{2} \mathbb{D}$ and Paweł Kochmański ${ }^{3} \mathbb{D}$ \\ 1 Department of Machine Design \& Mechatronics, Faculty of Mechanical Engineering, Lublin University of \\ Technology, Nadbystrzycka 36, 20-618 Lublin, Poland; m.ferdynus@pollub.pl \\ 2 Faculty of Marine Engineering, Maritime University of Szczecin, Willowa 2-4, 71-650 Szczecin, Poland; \\ k.gawdzinska@am.szczecin.pl \\ 3 Faculty of Mechanical Engineering and Mechatronics, West Pomeranian University of Technology, \\ al. Piastow 19, 70-310 Szczecin, Poland; pawel.kochmanski@zut.edu.pl \\ * Correspondence: m.rogala@pollub.pl
}

Citation: Rogala, M.; Ferdynus, M.; Gawdzińska, K.; Kochmański, P. The Influence of Different Length Aluminum Foam Filling on Mechanical Behavior of a Square Thin-Walled Column. Materials 2021, 14, 3630. https://doi.org/10.3390/ ma14133630

Academic Editor: Frank Czerwinski

Received: 26 May 2021

Accepted: 25 June 2021

Published: 29 June 2021

Publisher's Note: MDPI stays neutral with regard to jurisdictional claims in published maps and institutional affiliations.

Copyright: (c) 2021 by the authors. Licensee MDPI, Basel, Switzerland. This article is an open access article distributed under the terms and conditions of the Creative Commons Attribution (CC BY) license (https:/ / creativecommons.org/licenses/by/ $4.0 /)$.

\begin{abstract}
The demand for lightweight, strong structural profiles is currently high in the transport industry, mechanical engineering, and construction. Therefore, it is important to evaluate their properties, especially mechanical properties. The main objective of this paper is to determine energy absorption coefficients and evaluate the crush resistance of thin-walled aluminum profiles using numerical simulation and empirical verification. This paper presents the compression results of testing of thin-walled aluminum profiles filled with a porous material (cast aluminum foam). The numerical analysis was conducted using the software Abaqus/CAE. Aluminum material data were obtained from a static tensile test performed on a Shimadzu machine. The experiment was performed on an Instron CEAST 9450HES dynamic hammer. Profiles with three shapes of crush initiators filled with aluminum foam measuring $40 \mathrm{~mm}-200 \mathrm{~mm}$ in $20 \mathrm{~mm}$ increments were numerically tested. A sample with a concave initiator filled with foams of $40 \mathrm{~mm}, 60 \mathrm{~mm}, 80 \mathrm{~mm}$, and $120 \mathrm{~mm}$ in length was used to verify the numerical analyses. Energy absorption coefficients were determined from the analyses. The results of both analyses were tabulated to show the percentage differences. The study showed an increase in the Crush Load Efficiency (CLE) index by up to $33 \%$ for samples with the same crush initiator. In addition, it was noted that the use of porous fill does not increase the value of initiating Peak Crushing Force (PCF), which indicates the generation of much smaller overloads dangerous for vehicle passengers.
\end{abstract}

Keywords: energy absorber; thin-walled structures; dynamic crush; foam filling; aluminum foam; porous structures

\section{Introduction}

In the automotive industry, user safety remains an important factor in vehicle design. As early as the beginning of the 20th century, the first solutions were used to protect the main components of the vehicle as well as the occupants in the vehicle. In the 1960s, the first regulations defining safety considerations in vehicles appeared [1].

Initially, the protective element was a bumper made of a flat steel bar attached to the front supporting parts of the vehicle. Over time, the design of this area of the vehicle began to change, plastic bumpers and foam inserts appeared, which had energy-absorbing properties [2]. In the 1990s, additional energy-absorbing elements called crash-boxes appeared in the design of the crumple zone in the form of thin-walled metal structures mounted on the stringers. The purpose of crash-boxes is to absorb a large portion of the energy and protect the stringers, which are extremely expensive to repair, during collision speeds of up to $15-20 \mathrm{~km} / \mathrm{h}$.

Manufacturers of new vehicles have to meet increasingly stringent requirements, which often seem to be contradictory. On the one hand, it is necessary to maximize the 
amount of energy absorbed by the crush zone, and on the other hand, not to generate large overloads, which is related to the occurrence of PCF (Peak Crushing Force) at the beginning of the crush [3]. To meet these requirements, designers experimented with thin-walled profiles with different cross-sections, which were often adapted to the cross-sectional shape of the stringer. The first scientific papers on these problems appeared [4]. In the 1980s, Abramowicz worked on the study of axial dynamic crushing in both square and circular section models $[5,6]$ using analytical and experimental considerations. Specimens differing in the ratio of wall thickness to profile height were analyzed. Hanssen et al. [7,8] were among the first researchers in the area of foam-filled energy absorbers. The papers presented considerations on how to model the foam issue and the energy absorption of aluminum fillings with different densities under static and dynamic loading. Kaczynski et al. presented a quasi-static and dynamic study of energy absorption by aluminum and composite foams depending on their manufacturing technology [9]. The protection of passengers (and cargo, environment) is also not without significance, e.g., protection from leakage of photovoltaic cell batteries located in the chassis of motor vehicles, and other related issues to fire protection. For example, design principles are described due to thermal and mechanical actions on structures under fire conditions. Fire-resistant aluminum structures can also be helpful, especially aluminum profiles and foams. Hipke et al. in [10] presented an interesting study on layered aluminum foam core materials. They described the high stiffness of these structures with low weight and high fire resistance. They proved that these materials protect electromagnetic waves and show significant vibration reduction and acoustic isolation. In one of the authors' works [11], a study of the fire resistance of aluminum and aluminum-ceramic foams is presented.

Porous structures also find their application during the study of sandwich-type structures [12]. Metal or metal-ceramic foams are covered with plate elements that havedifferent mechanical properties. By using foam filling, a significant increase in the absorbed energy can be observed in the three-point bending test. An interesting approach in the study of porous materials was presented by Duarte et al. [13], where the open-pore foam was flooded with a polymer. The filling formed a composite structure, the effect of which positively affected the energy absorption performance. However, the authors noted that filling a thin-walled profile fully causes damage to the aluminum column during dynamic testing due to too much polymer inside. Many works investigating porous fillings focus on changing the cross-sectional area through various types of cut-outs $[14,15]$. The authors present the concept of cut-outs with bio-inspired shapes such as squares along with the profile (cornstalk). All the literature aptly considers reducing the amount of porous material; however, none have researched the area of reduction in fill length and its effect on crush efficiency indices.

At the beginning of the 21st century, a theoretical work [16] was presented that focused on the failure of models, both multi-cell and those with foamed material filling [17]. In modern designs, energy absorbers are usually made with a so-called crush initiator called a trigger. Its task is to induce the start of the plastic process in a precisely defined place. Many studies [18,19], as well as works of the authors [20,21], show that the presence of the trigger significantly reduces the PCF value and thus improves the CLE index (Crush Load Efficiency); however, it is accompanied by a smaller portion of energy absorbed during the generation of the first fold. Therefore, the idea of partial foam filling, which is the subject of this article, was developed to improve energy absorption without significantly changing the performance characteristics, as is the case with "full" filling. The use of foam with an appropriate density does not significantly increase the value of PCF, but it dramatically improves the energy-absorbing properties by increasing the MCF (Mean Crushing Force).

In many studies, the authors focused on maximizing the amount of energy absorbed by a thin-walled structure concerning its SEA mass; in this case, it was easily achieved by using multi-cell [22,23] or bi-tubular [24,25] thin-walled profiles, also filled with foam of an appropriate density [26,27] or honeycomb [28-30] structures. The use of multi-cell structures is a solution that is becoming more popular; however, such solutions do not usually 
fulfill an important condition set for biomechanical reasons, namely the minimization of overload that occurs during crushing.

As mentioned above, a method to avoid the increase of PCF force while increasing the energy efficiency of the energy absorber is to use foamed material fillings; this is especially true for mono-cell profiles, which are characterized by lower values of PCF forces compared with multi-cell profiles.

The high energy performance of thin-walled structures is a result of the mechanism of crush progression. Local loss of stability occurs in areas of imperfection, which appear naturally or are forced by geometric disturbances in the form of a crush initiator. In literature, many positions describe the deformation process of the thin-walled model, of which the so-called progressive crush is the most desirable [31]. In order to obtain this form of deformation in the thin-walled structure, apart from the essential dimensions of the energy absorber, especially its slenderness, important factors include the presence, location as well as shape of the crush initiator [28]. When analyzing issues with many factors whose significance and influence are difficult to grasp, the use of artificial intelligence methods seems unrivaled. During regression analyses, it is possible to find relations between input data, e.g., geometrical variables related to the shape and position of the crush initiator, and output data, i.e., crush efficiency indexes [32,33]. It is also possible to predict the values of these parameters for obtaining desired energy-absorbing properties, which significantly reduce the time and cost of calculations.

\section{Crashworthiness Indicator}

The basic quantity determined during analysis was the amount of mechanical energy dissipated during the dynamic crushing process. Its measure is the area under the curve shown in Figure 1 and is given by the formula:

$$
E A=\int_{0}^{d} F(x) d x,[J]
$$

The value of this energy is generally related to the mass of the energy-absorber, which is denoted as SEA (Specific Energy Absorption), and is given by the formula below:

$$
S E A=\frac{E A}{m},\left[\frac{J}{k g}\right]
$$

Another indicator is the Mean Crushing Force-MCF (Figure 1), which occurs during crushing and is defined as the ratio of energy absorbed to total crushing distance:

$$
M C F=\frac{E A}{d_{x}},[N]
$$

where:

EA-energy absorbed;

$d_{x}$ - crushing distance.

An important parameter is the Peak Crushing Force $(P C F)$ value, which is shown in Figure 1. The value of this force directly affects the maximum overloads that occur at the beginning, and their duration will determine the probability of severe injury and the chances of survival. 


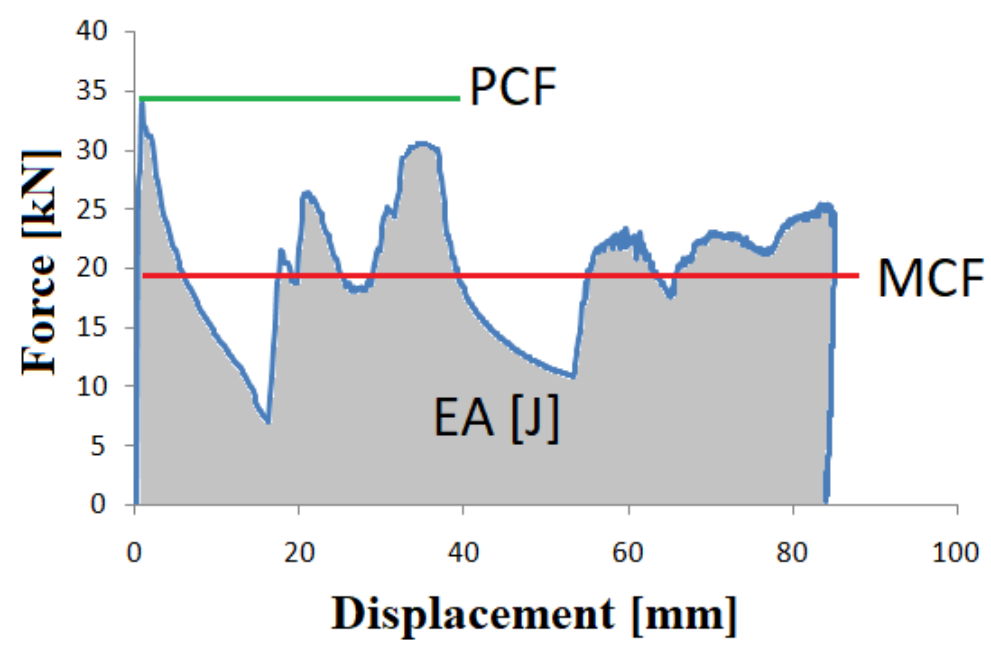

Figure 1. Example of force-displacement characteristics of an energy absorber.

The ratio of the average crush force $M C F$ to the maximum crush initiating force $P C F$ is referred to as the CLE ratio and is given by the equation:

$$
C L E=\frac{M C F}{P C F}[-]
$$

For biomechanical reasons, it is advantageous to crush as long a displacement as possible; hence the SE ratio of displacement to initial specimen height:

$$
S E=\frac{U}{L_{0}},[-]
$$

where:

$L_{0}$-initial specimen length [mm];

$U$-maximum specimen shortening (crushing distance) [mm].

The last indicator that comprehensively shows the performance of the energy absorber is the Total Efficiency (TE), and it is represented as the product of the indicators in Equations (4) and (5).

$$
T E=C L E \times S E[-]
$$

\section{Materials and Models}

The subject of the analysis was a profile with a square cross-section. The model was filled with a porous aluminum material of different lengths. The dimensions of the aluminum profile were $200 \mathrm{~mm}$ high, a cross-section of $40 \times 40 \mathrm{~mm}$, and a sidewall thickness of $1.2 \mathrm{~mm}$ (Figure 2). The length of the foam fill occurred from $40 \mathrm{~mm}$ to $200 \mathrm{~mm}$ every $20 \mathrm{~mm}$. The aluminum foam was manufactured as a block ex situ. Then, after cutting to the specified size, it was pressed inside the profile. Using such technology made it possible to obtain a structure with identical properties in each of its places, and the pores produced reached similar sizes for the whole structure. 


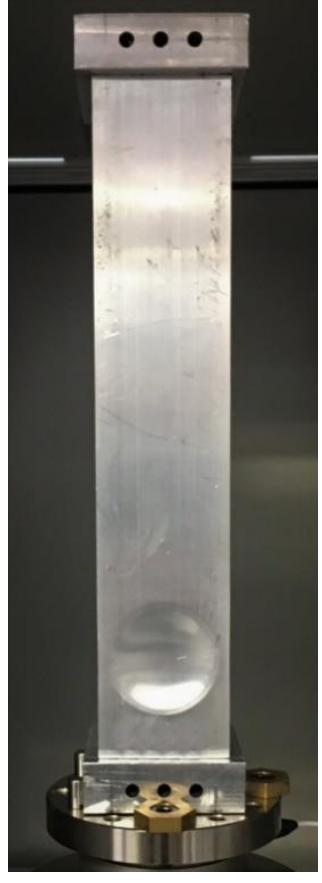

(a)

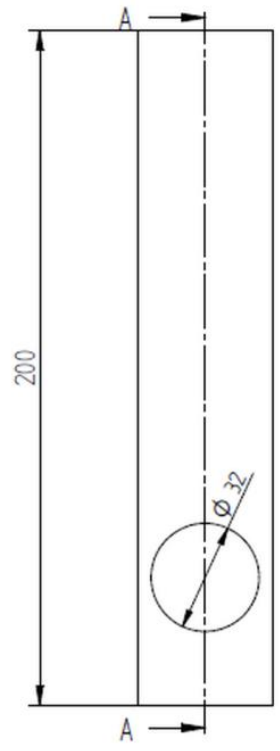

(b)

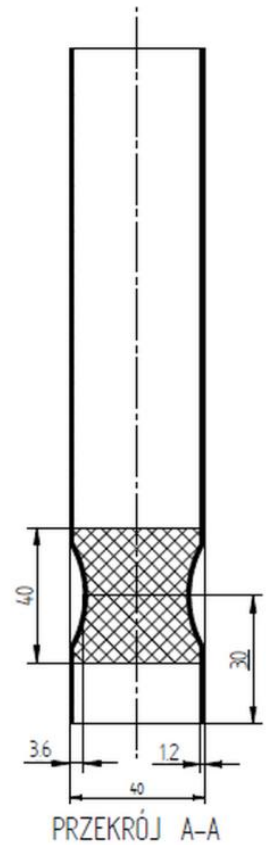

Figure 2. (a) Physical view of the specimen attached to the test table; (b) The technical drawing with dimensions of the C32 model filled with $40 \mathrm{~mm}$ length foam.

The material model of the aluminum column was defined as elastic-plastic. Currently, for dynamic problems, the Johnson-Cook constitutive material model considers the strain rate as most commonly used [34]. In many works, this decision was justified by showing large discrepancies for different velocities of the given load, especially during the explosion study. However, based on Wizner's research [35], aluminum alloys with T6 heat treatment show that load dynamics do not affect the strain rate. Given these results, the model was simplified to minimize the computational cost. The material data of EN AA6060T6 aluminum was obtained by static tensile testing. The elastic properties were based on Young's modulus and Poisson's ratio, where as the plastic properties were based on multi-linear characteristics of the stress-strain relationship. The obtained data are shown in Table 1.

Table 1. Material properties of aluminum (own research).

\begin{tabular}{cccc}
\hline AA.-6060-T6 & & Stress $\boldsymbol{\sigma}[\mathrm{MPa}]$ & Strain $\varepsilon[-]$ \\
\hline Density $\rho\left[\mathrm{kg} / \mathrm{m}^{3}\right]$ & 2700 & 200 & 0 \\
\hline Young's Modulus E $[\mathrm{MPa}]$ & 70,000 & 249.35 & 0.00248 \\
\hline Poisson's Ratio $[-]$ & 0.33 & 279.98 & 0.0598 \\
\hline
\end{tabular}

The foam material in the plasticity field was modeled as Crushable foam [36]. The necessary data have yield strength in uniaxial compression $\sigma_{c}^{0}$, initial yield stress in hydrostatic compression $p^{0}{ }_{c}$, yield strength in hydrostatic tension $p_{t}$, and plastic Poisson's ratio $v_{p}$. The foamed material data are shown below in Table 2 and Figure 3. 
Table 2. Basic parameters of ALPORAS aluminum foam [37].

\begin{tabular}{cccccc}
\hline & $\begin{array}{c}\text { Density } \\
{\left[\mathrm{kg} / \mathrm{m}^{\mathbf{3}}\right]}\end{array}$ & $\begin{array}{c}\text { Young's } \\
\text { Modulus } \\
{[\mathrm{MPa}]}\end{array}$ & $\begin{array}{c}\text { Poisson's } \\
\text { Ratio [-] }\end{array}$ & $\begin{array}{c}\text { Plastic } \\
\text { Poisson } \\
\text { Ratio } v_{\boldsymbol{p}}[-]\end{array}$ & $\begin{array}{c}\text { Compression } \\
\text { Yield Stress Ratio } \\
\boldsymbol{p}^{\mathbf{0}}{ }_{c}[\mathrm{MPa}]\end{array}$ \\
\hline $\mathrm{AL}$ & 292 & 60 & 0.33 & 0.015 & 1.702 \\
\hline
\end{tabular}

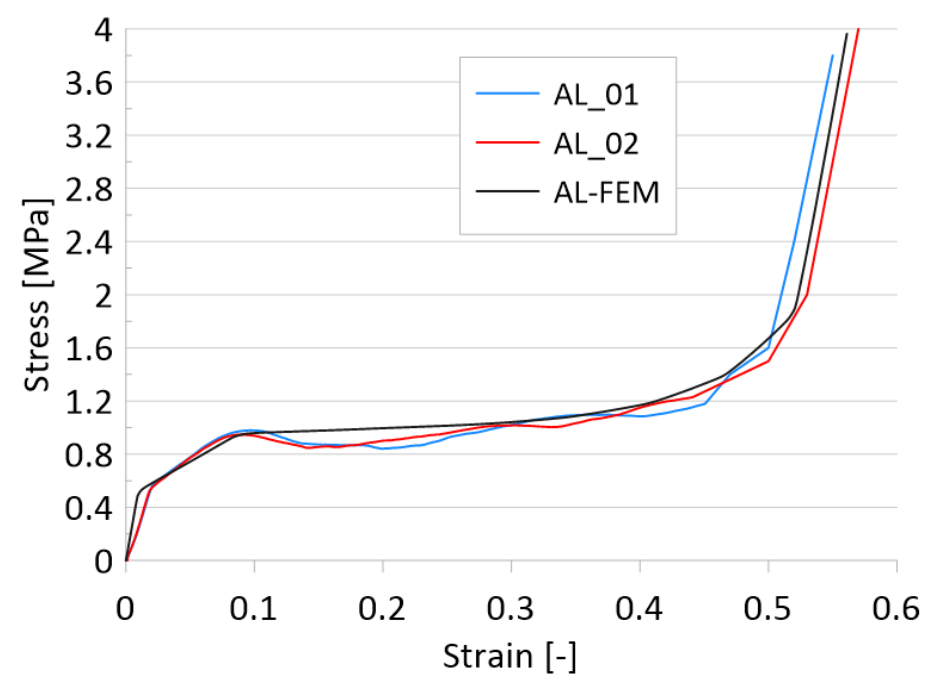

Figure 3. Stress-strain curve of the foamed material.

The results of the test presented above were obtained using a Comatech test machine. The dimensions of the sample were determined based on the literature position [38], where the author described the relationship between the height, width, and length of the sample. The aluminum foam was cut to the size of $40 \times 40 \times 20 \mathrm{~mm}$. The speed of the compression plates was determined to be $2 \mathrm{~mm} / \mathrm{min}$. The test was repeated twice, and the result was compared with FEM analysis to validate the material model.

In order to validate the provably modeled porous material, a cubic sample was subjected to a compression test. The characteristics in Figure 3 show two experimental specimens labeled AL_01 and AL_02. The curve obtained from the numerical analysis is AL-FEM and reflects high accuracy, confirming the correct modeling of the porous structure.

The modeled material described above is based on constitutive equations, where the yield surface for isotropic hardening can be described as follows:

$$
F=\sqrt{q^{2}+\alpha^{2} p^{2}}-B=0
$$

where:

$$
p=-\frac{1}{3} \text { trace } \sigma, \quad q=\sqrt{\frac{3}{2} \sigma_{d e v}: \sigma_{d e v}}
$$

$p$-pressure stress, $q$-von Mises stress.

Parameter $B$ is the size of yield ellipse related to the hydrostatic compression $p_{c}$ :

$$
B=\alpha p_{c}=\sigma_{c} \sqrt{1+\left(\frac{\alpha}{3}\right)^{2}}
$$

The yield surface represents the Mises circle in the deviatoric stress plane. The shape factor, $\alpha$, can be computed using the initial yield stress in uniaxial compression $\sigma^{0}{ }_{c}$, and 
the initial yield stress in hydrostatic compression, $p_{c}^{0}$ (the initial value of $p_{c}$ ), using the dependencies:

$$
\alpha=\frac{3 k}{\sqrt{9+k^{2}}} \quad \text { with } \quad k=\frac{\sigma_{c}^{0}}{p_{c}^{0}}
$$

\section{Methodology of FEM}

The analysis for each model was performed in two steps. The first was a buckling analysis, which was implemented into the dynamic analysis. The boundary conditions were reduced to those prevailing during the experimental study. The model was restrained by creating a non-deformable plate to which the aluminum profile was connected by a Tie relation. The load was modeled by assigning mass to the non-deformable plate and defining its initial velocity afterward (Figure 4). The modeled foam was connected with the profile only when friction force was applied as a contact definition. The friction ratio was set as 0.2 .
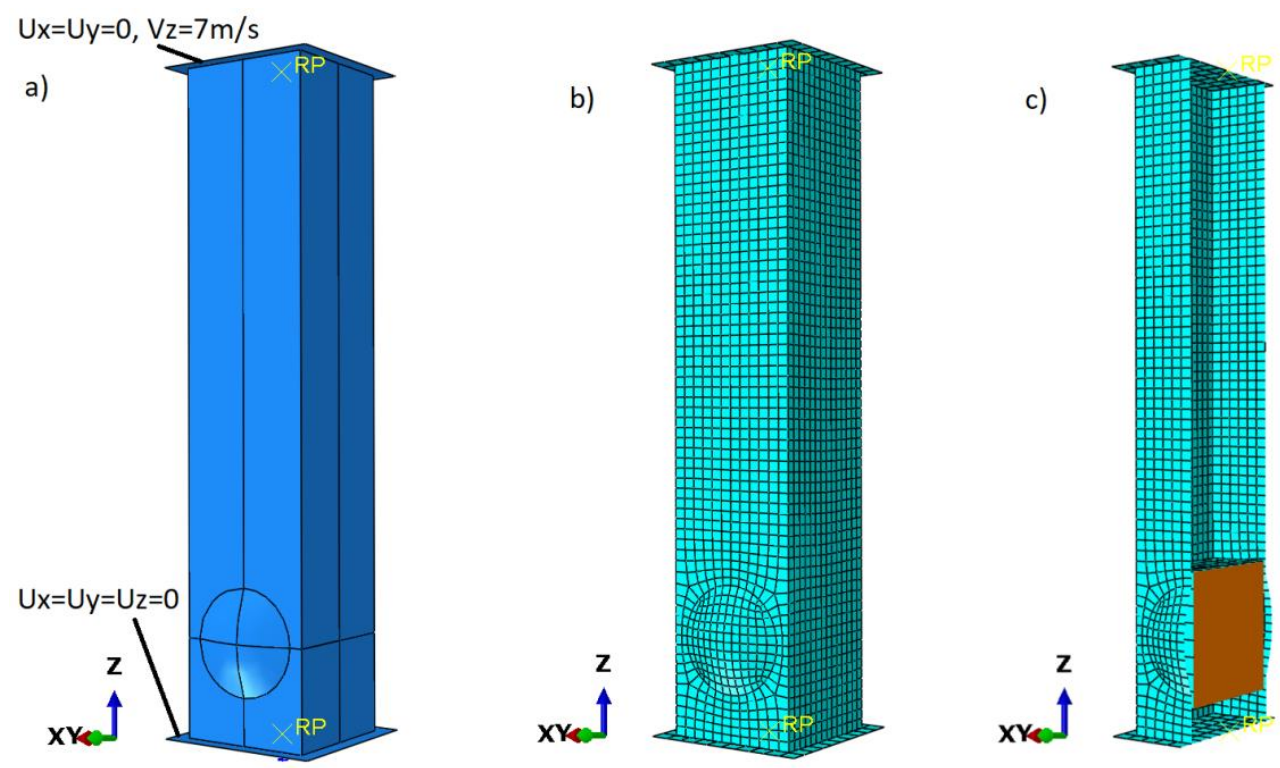

Figure 4. Numerical model (a) Boundary conditions; (b) discretized numerical model; (c) cross-section of the discretized foam-filled model.

The mass assigned to the plate was $70 \mathrm{~kg}$, and its velocity was $7 \mathrm{~m} / \mathrm{s}$, which provides a kinetic energy of approximately $1700 \mathrm{~J}$. The analysis of the problem was based on three geometric models with circular crush initiators. The first imperfection was a concave surface on the opposite side, with a diameter of $32 \mathrm{~mm}$, and an indentation depth of $3.6 \mathrm{~mm}$. The distance from the center of the circle to the bottom edge of the model is fixed at $30 \mathrm{~mm}$. This model is referred to as the letter $C$ in the results (Figure 5). The second type of initiator has a convex surface on its side with the same dimensions as in model C. During data analysis, the model was denoted by the letter $\mathrm{B}$. The last model has convex surfaces on opposing faces and concave surfaces on the other two faces. It has geometric parameters as in the previous models and is denoted by the letters BC. 


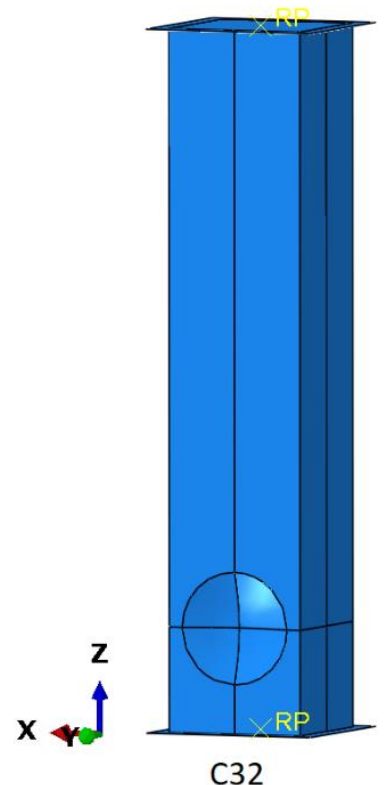

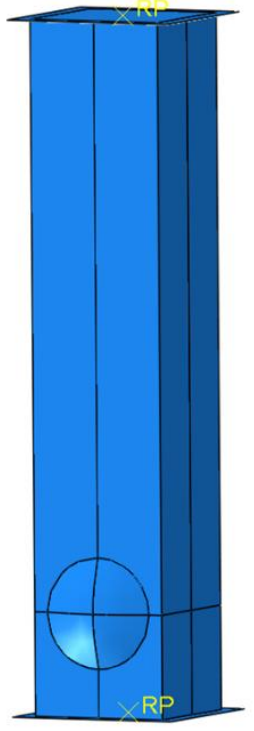

B32

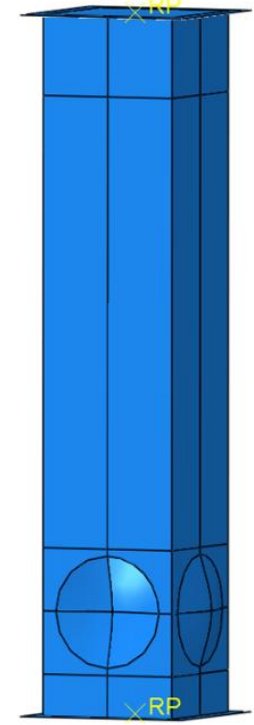

BC32

Figure 5. Types of models used in the numerical analysis.

\section{Experimental Studies}

The impact test was performed on an Instron CEAST 9350HES hammer, the general appearance of which is shown in the image below (Figure 6). The stand consists of a test table onto which the specimen is attached. In addition, the dynamic testing hammer has a tup to which the mass is applied, thus translating into the energy obtained.

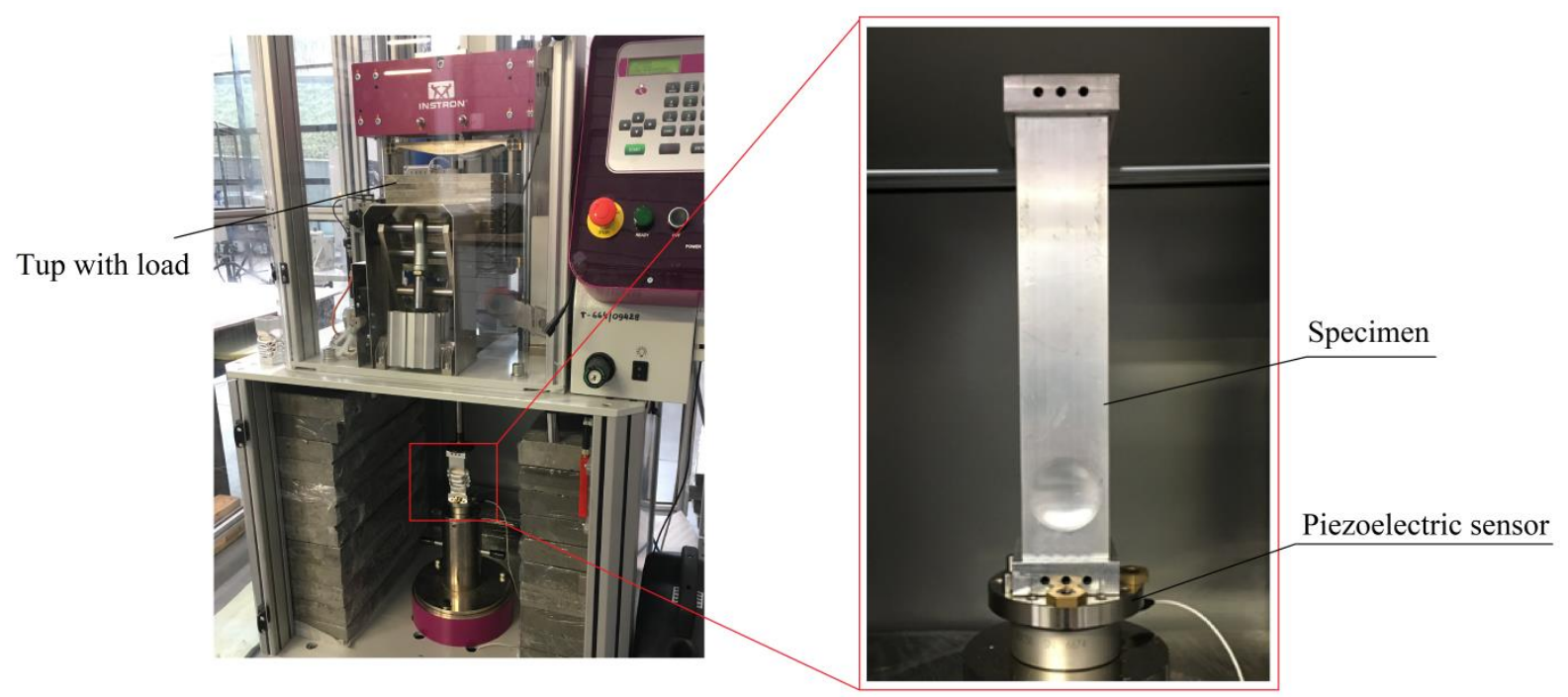

Figure 6. General appearance of the experimental test station and specimen location.

The fixing of the sample was done with dedicated aluminum cubes whose dimensions were matched to the internal dimensions of the profile. The purpose of the grips was to stabilize the specimen during crushing and properly translate the impact of the tup into the crushing of the absorber.

\subsection{Foam Fabrication}

In this paper, porous structures with density $0.292 \mathrm{~g} / \mathrm{cm}^{3}$ and porosity $91.02 \%$ were used for foaming in a liquid state. Foaming in a liquid state implements a foaming agent in the form of a TiH2 compound into liquid aluminum thickened with calcium. As a result of 
chemical reaction, the foaming of liquid aluminum occurs. After adequate cooling of the foam, the finished product is obtained. The scheme of the method is shown in Figure 7.

a)

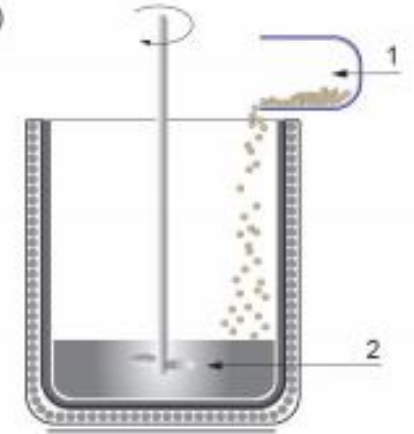

c)

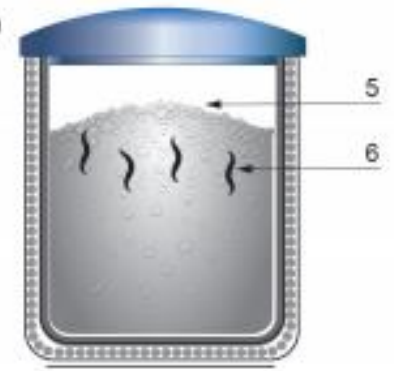

b)

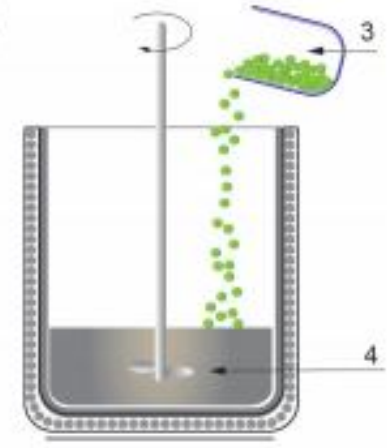

d)

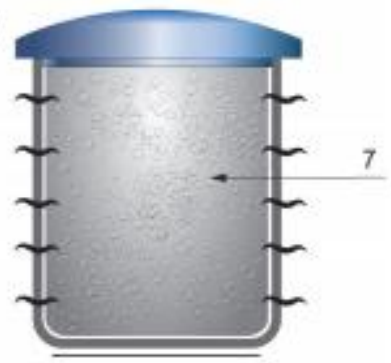

Figure 7. Scheme of the foaming method in the liquid state: (a) thickening, $1-\mathrm{Ca}$ additive, 2-liquid aluminum; (b) 3-foaming agent TiH2, 4-thickened aluminum; (c) foam formation as a result of the chemical reaction, 5-foamed aluminum, 6-foam drainage; (d) foam cooling, 7-finished product of aluminum foam (own elaboration based on [39-41]).

This method is the most common way of manufacturing metal foams and allows the shaping of finished products during the technological process with repeatable structure parameters [39-43]. The foam produced was subjected to SEM-EDS analysis which showed the percentage (mass) of elements for the selected points. The averaged values were $81.2 \%$ $\mathrm{Al}, 4.1 \% \mathrm{Ca}, 6.3 \% \mathrm{Ti}, 8.0 \% \mathrm{Fe}$, and $0.4 \% \mathrm{Ni}$, respectively.

\subsection{Experimental Specimen}

A model with a concave crush initiator described as C32-3 was experimentally tested on. Five experimental tests were performed. The specimens included a C32 empty profile and four aluminum foam-filled models with lengths of $40 \mathrm{~mm}, 60 \mathrm{~mm}, 80 \mathrm{~mm}$, and $120 \mathrm{~mm}$. The thin-walled models were made of EN AA6060-T6 aluminum alloy. The cross-section size was $40 \mathrm{~mm} \times 40 \mathrm{~mm}$, with a wall thickness of $1.2 \mathrm{~mm}$. Profile height was $200 \mathrm{~mm}$. A crush initiator was embossed on the surfaces of two sides using a hydraulic press and a dedicated die. The shape of the indentation is shown in the following graphic (Figure 8a), and corresponds to the initiator on the numerical model.

Figure 8a, shown above, figuratively describes the fabrication of a thin-walled specimen with a round trigger stamped on it. The dedicated die adjacent to the profile on the left consists of two parts fastened together with a screw. It is inserted into the center of the profile, and the initiator shape is then embossed using a hydraulic press and special rubber. Finally, aluminum foam (Figure $8 \mathrm{~b}$ ) of a specified length $(60 \mathrm{~mm}$ in the picture) is pressed into the profile. 


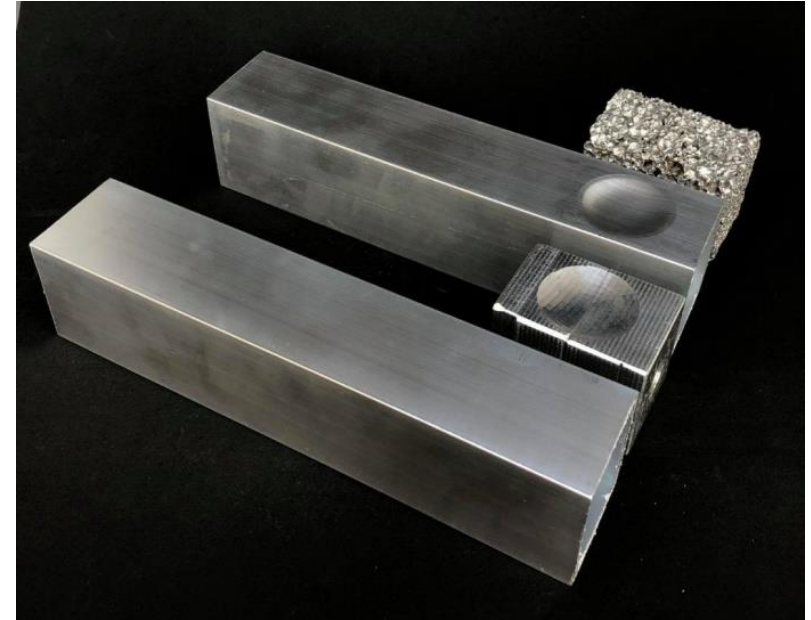

(a)

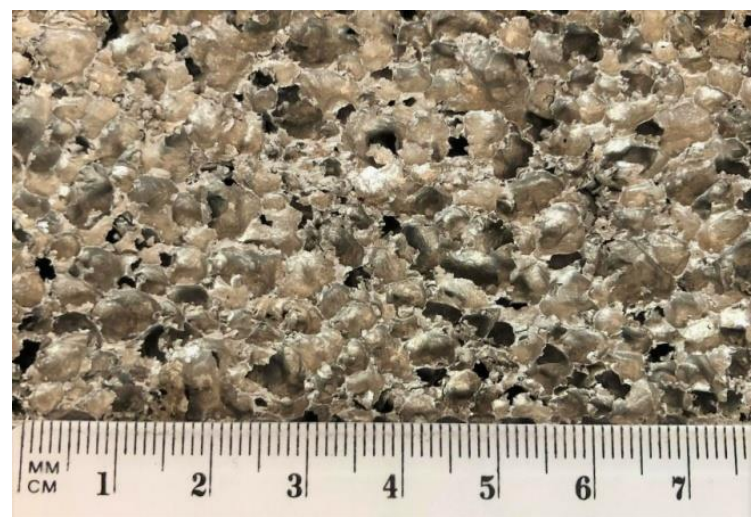

(b)

Figure 8. (a) The shape of the experimental specimen with matrix and foam filling presentation; (b) close-up of porous structure.

\section{Results of Experimental Study}

In the experimental analysis, $40 \mathrm{~mm}, 60 \mathrm{~mm}, 80 \mathrm{~mm}, 120 \mathrm{~mm}$ foamed samples and an unfilled control sample were tested. All the experimentally tested specimens had an initiator in the form of a concave surface denoted by the letter $\mathrm{C}$ in the numerical studies. Figures 9 and 10 show the characteristics of the force-shortening relationship. The results are compared with the curve obtained during the numerical analysis.

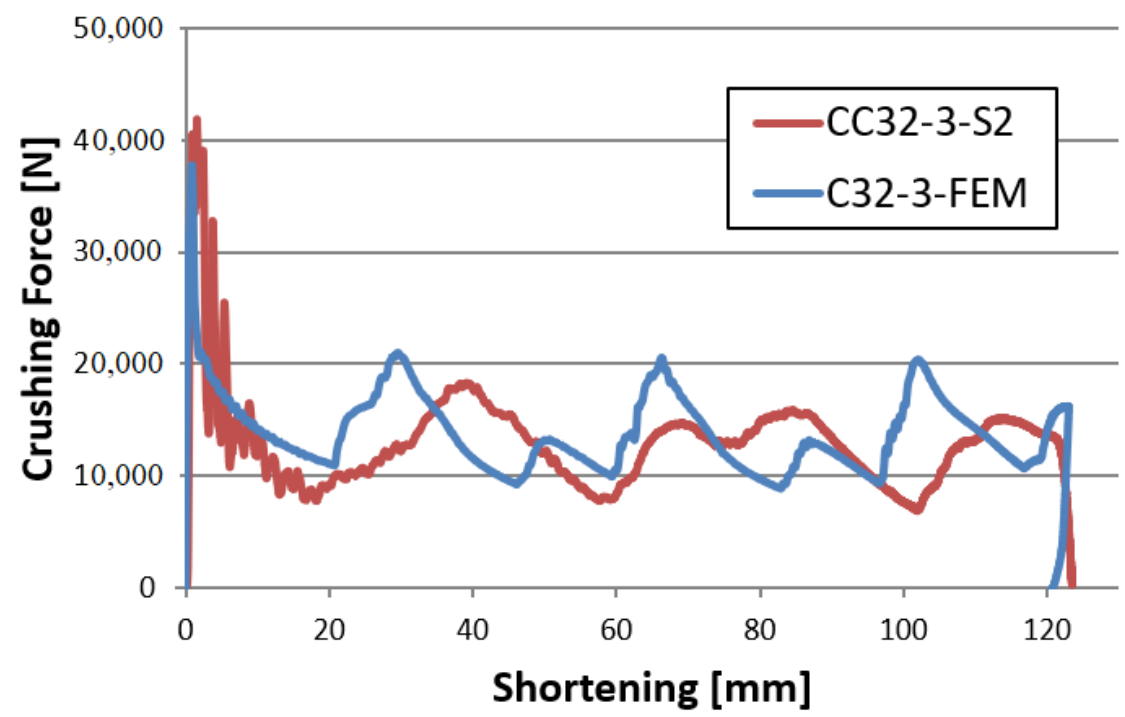

Figure 9. The force-shortening curve for an empty model with a concave crush initiator.

The above graph compares numerical and experimental characteristics of samples without filling with a porous material. It functions as a control absorber to which the foam-filled profiles are compared. Based on the characteristic curves and the crushing efficiency ratios, it is possible to determine the influence of the porous structure on the absorber performance. The PCF occurs at the beginning of the analysis and reaches a value of approximately $40 \mathrm{kN}$. On the graph, force peaks can be seen, which correspond to the formation of plastic hinges whose number and occurrence in numerical and experimental analyses are similar, proving the convergence of both analyses. 


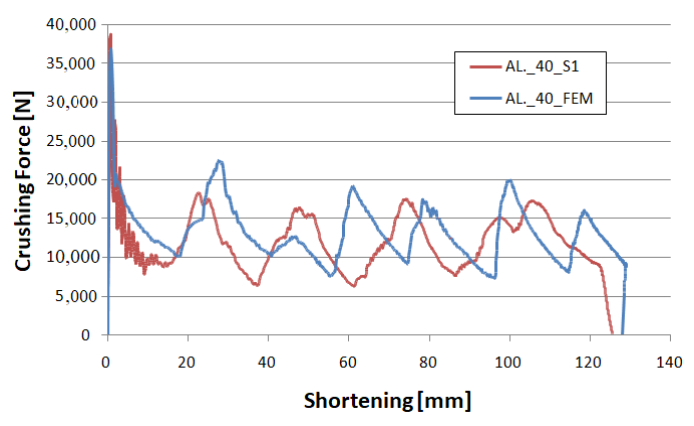

(a)

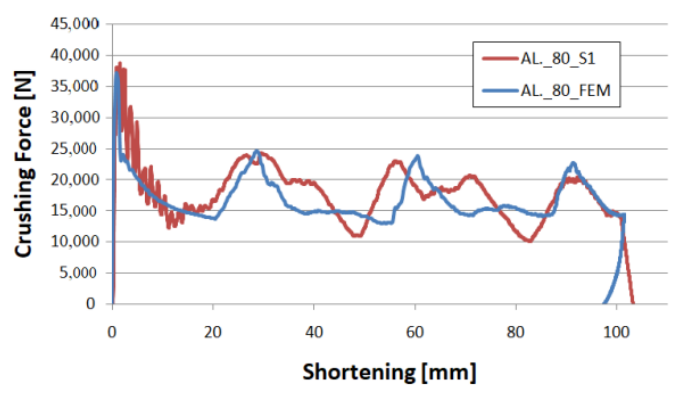

(c)

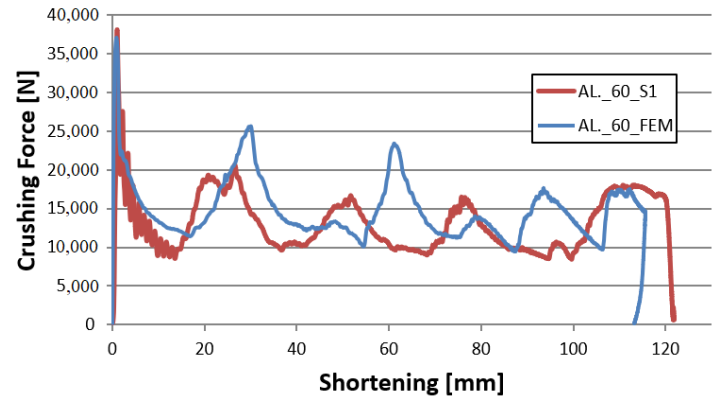

(b)

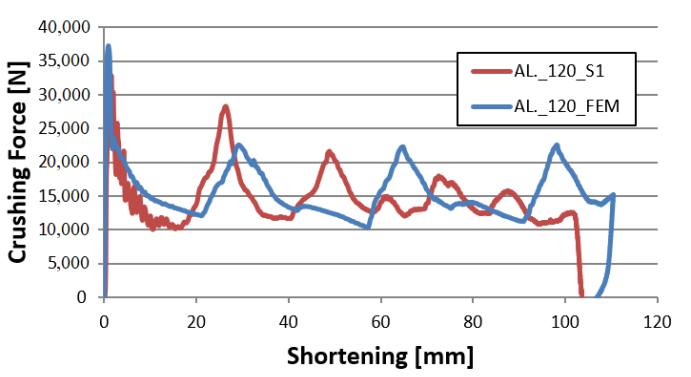

(d)

Figure 10. Experimental and numerical force-shortening diagram: (a) column with $40 \mathrm{~mm}$ foam filling; (b) column with $60 \mathrm{~mm}$ foam filling; (c) column with $80 \mathrm{~mm}$ foam filling; (d) column with $120 \mathrm{~mm}$ foam filling.

Figure 10a-d compares force-shortening characteristics for the experimental and numerical analyses. In the graphs, we can see the shortening of the profile during dynamic crushing as well as the force values. The changing force indicates the formation of plastic hinges on thin-walled profiles. In the crush analysis, it is important to note how many plastic hinges were formed and in which places. A correlation of force peaks can be seen in the graphs, indicating that the absorbers behave similarly. In the case of the $120 \mathrm{~mm}$ foam sample, the last force peak splits into two smaller peaks. This behavior in the models may be due to material inhomogeneity or imperfections in the geometric structure of the specimen. However, this does not translate into crush efficiency ratios as both MCF and CLE values remain similar to numerical data.

All specimens were tested at the same initial energy, i.e., $1700 \mathrm{~J}$, and the analysis was conducted until the value of the crushing force decreased to zero, i.e., until the total energy was absorbed by the profile. Testing at these initial conditions allows us to graphically determine the effect of porous material on the performance of the energy absorber from Figure 11. By observing successive profiles, one can see that the increasing height of the profile indicates that the same portion of energy was absorbed using a smaller length of the absorber. The higher the profile is, the greater the potential for the thin-walled structure to dissipate additional energy. Due to the skewness of specimens AL_40 and AL_60, which suffered a non-axial impact, an increase in specimen height with increasing foam insert length was not observed in this case.

Based on the obtained performance indicators and the course of force values, the numerical model was considered, validated and its reliability was confirmed. 


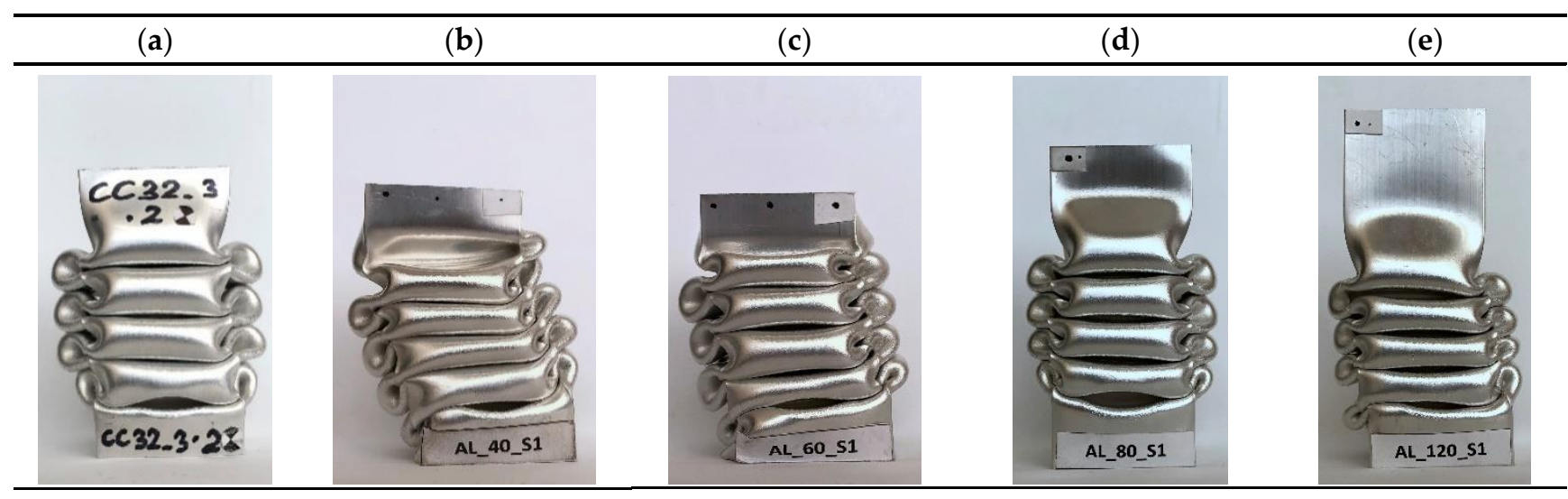

Figure 11. Comparison of experimentally tested specimens with foam length (a) $0 \mathrm{~mm}$, (b) $40 \mathrm{~mm}$, (c) $60 \mathrm{~mm}$, (d) $80 \mathrm{~mm}$, and (e) $120 \mathrm{~mm}$.

During the experimental analysis, the duration of the dynamic process (approximately $40 \mathrm{~ms}$ ) required the use of a high-speed camera. The time-lapse video can map the behavior of the thin-walled experimental specimen and then compares it with visualizations from numerical analyses. Images of characteristic moments of the dynamic crush, i.e., formation of consecutive folds, are shown in Figures 12 and 13.

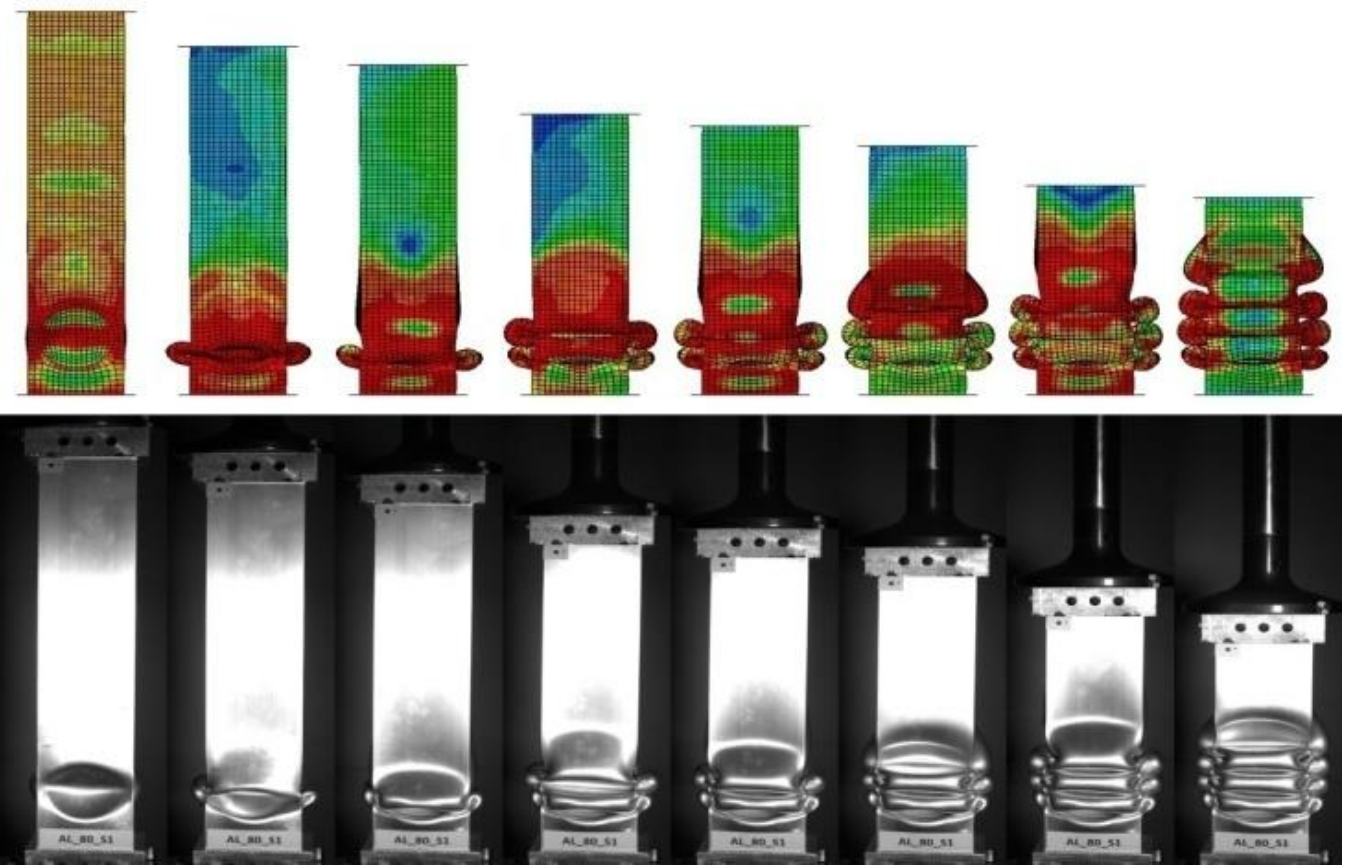

Figure 12. Comparison form of crushed absorber in different stages of dynamic analysis for $80 \mathrm{~mm}$ length foam. 


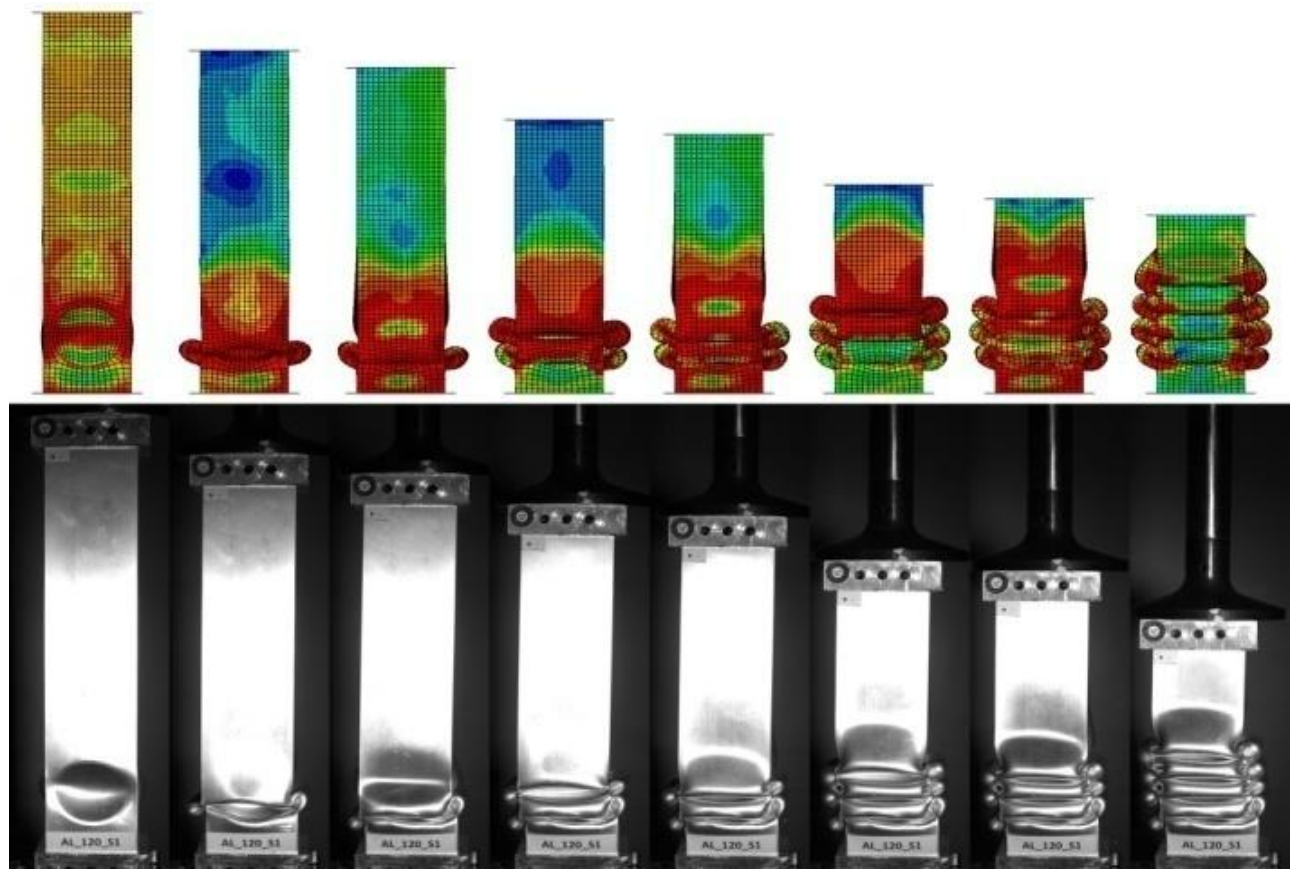

Figure 13. Comparison form of the crushed absorber in different stages of dynamic analysis for $120 \mathrm{~mm}$ length foam.

The camera was used to analyze two foam-filled samples measuring $80 \mathrm{~mm}$ and $120 \mathrm{~mm}$ in length. The specimens had markers to obtain the change in displacement and velocity through time. By acquiring data from the high-speed camera, we can compare the efficiency indicators with those obtained numerically and determine the discrepancy between the two analyses.

The graphic above (Figure 14) compares the cross-section of AL.60_S1 and AL._60_FEM. From the graphic, we can identify the shape of the plastic zones and their occurrence, as well as the behavior of the porous filling. The aluminum foam similarly fits into the folds and then deforms under the pressure of the aluminum profile walls. This process demonstrates a properly simulated material model and the manner in which the issue was modeled.

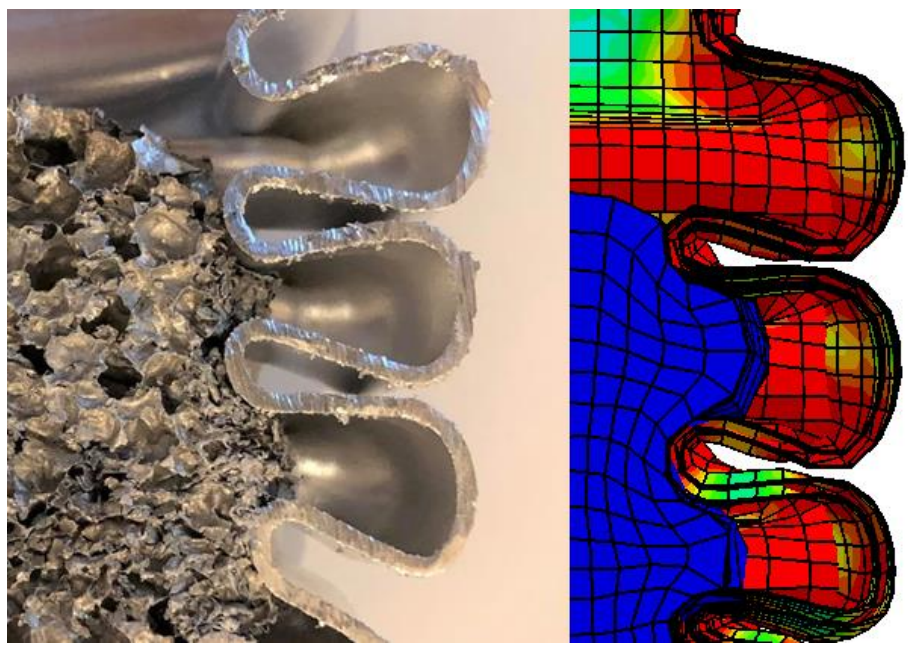

Figure 14. The shape of plastic hinges for a $60 \mathrm{~mm}$ long aluminum foam-filled specimen.

\section{Results of Numerical Analysis}

The tested models were divided into three groups due to the shape of the crush initiator. The aluminum profiles filled with foamed material were subjected to dynamic 
crushing with an initial energy provided of $1700 \mathrm{~J}$. Figure 15 shows the runs for all filling lengths for the concave-convex trigger denoted by $\mathrm{BC}$.

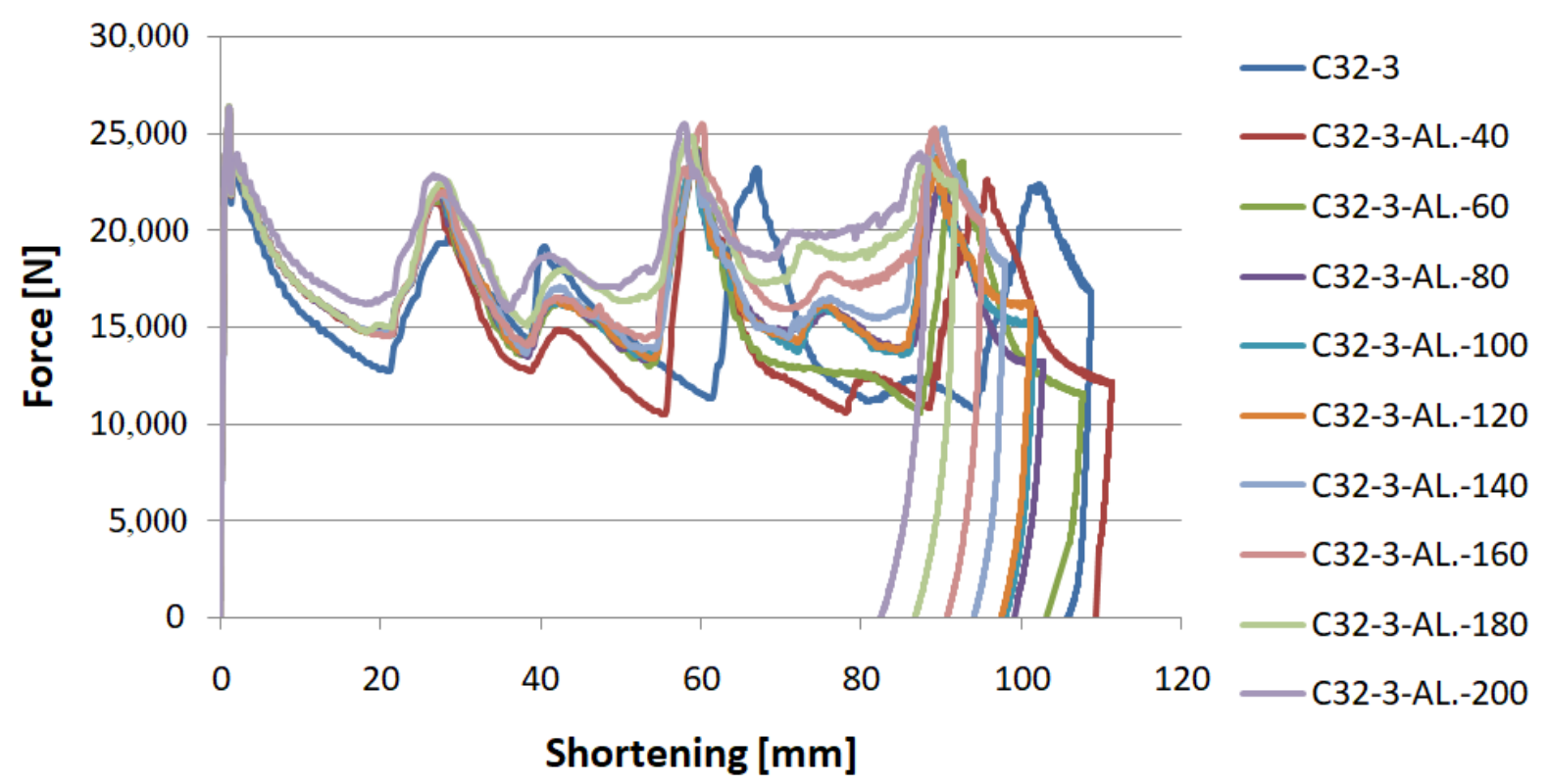

Figure 15. Force-shortening curves with different foam filling on an example of BC trigger.

The results were based on the indices described in Section 2, presented with Formulas (1)-(5). The most important index characterizing the energy absorber is the Crush Load Efficiency (CLE) presented in Figure 16.

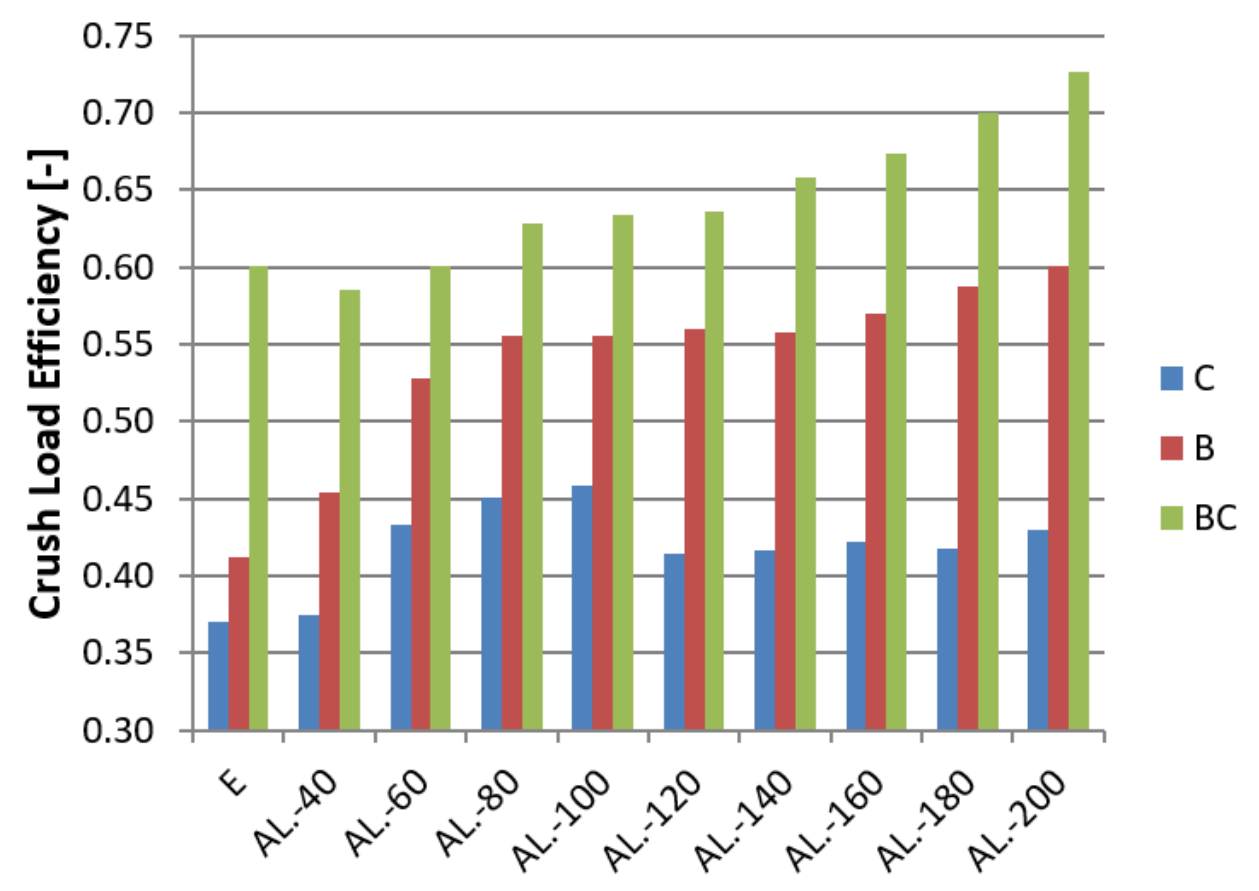

Figure 16. CLE indicator for all tested absorbers.

In the figures for each model (Figures 16-18), a specific type of trigger is presented, and the sample without foam filling is marked with the letter E (Empty). Observing the CLE coefficient, the influence of foam filling on its increase is noticeable. The highest increase is observed for models with a convex crush initiator. In the case of models B and $C$, a clear rise in performance can be seen for foams measuring $60-100 \mathrm{~mm}$ in length. 
Models with this foam range have the best capacity considering the amount of porous material used. Longer fill lengths marginally increase efficiency, and in the case of model C, there was none at all. For the $\mathrm{BC}$ model, due to the nature of the triggering operation, the foam was crushed at the initial stage, resulting in little change in the CLE rate for foam fill lengths less than $100 \mathrm{~mm}$. The MCF (Figure 16) value increases in a similar manner to the CLE index because of the value of the maximum force, which varies within a small range for individual initiators.

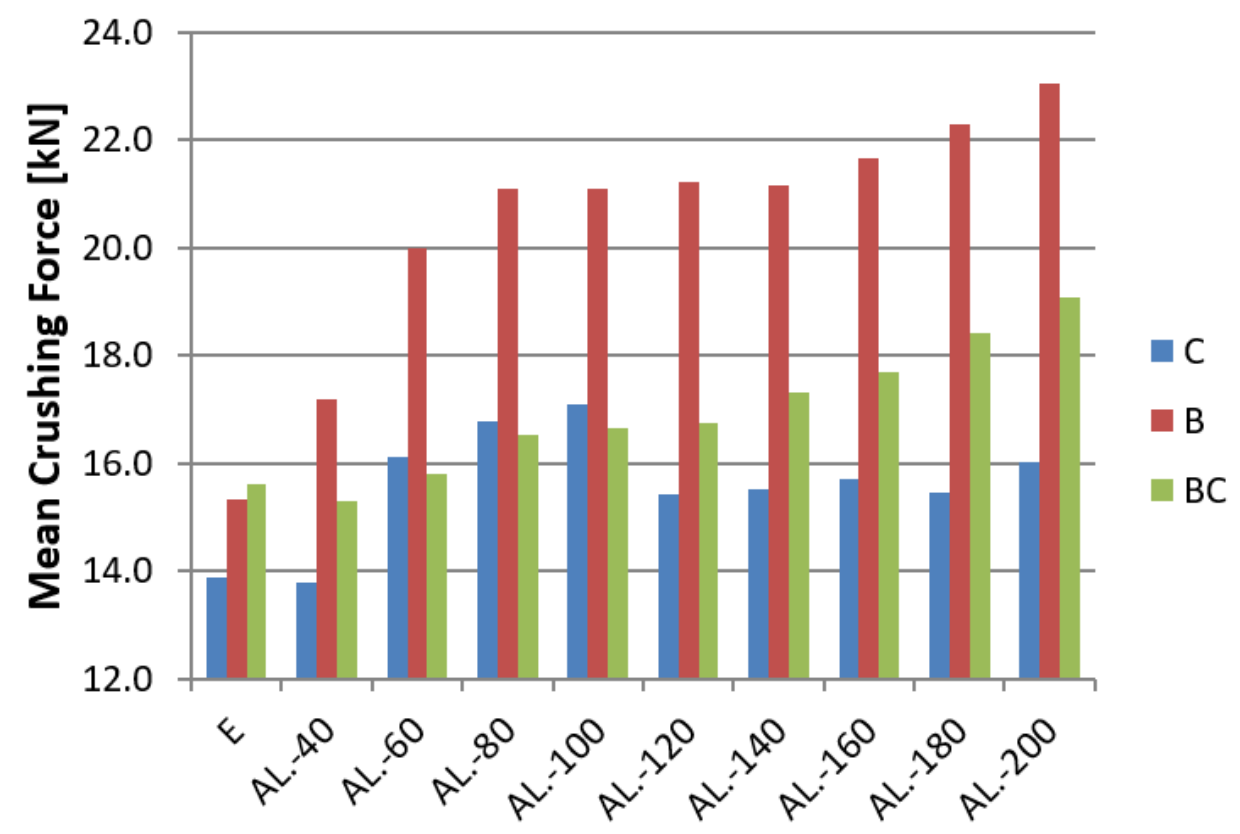

Figure 17. Mean Crushing Force for whole length range of aluminum foam filling.

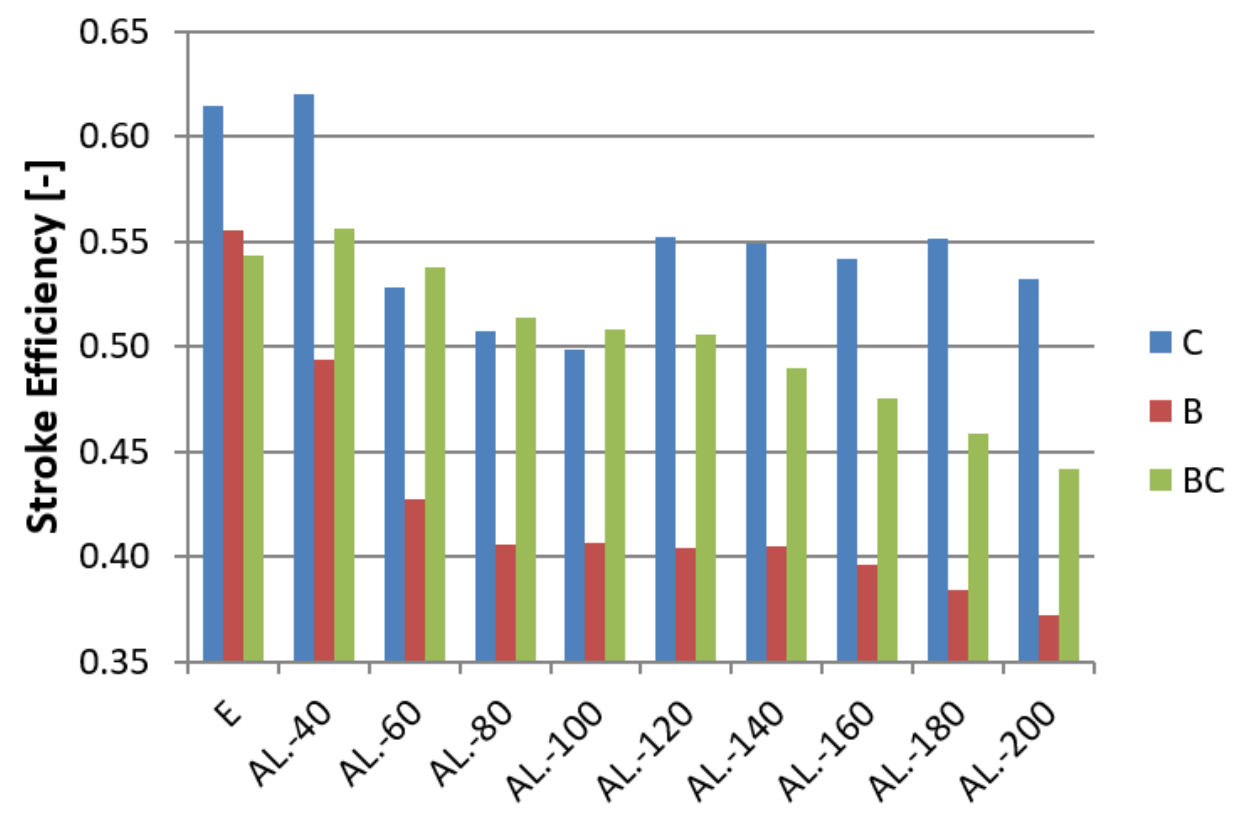

Figure 18. SE indicator for specimen filled with aluminum foam.

The average force increases with foam length for all trigger shapes. The jumping trend can be witnessed, especially for the $60-100 \mathrm{~mm}$ range where the increase in value is highest. 
The ratio of SE decreased by about $15-20 \%$ for extreme cases. The difference is visible, especially for the B and C models (Table 3). The smaller the SE ratio, the better the potential for energy absorption for a profile of the same length.

Table 3. Crashworthiness indicator of aluminum foam-filled columns with different trigger.

\begin{tabular}{ccccccccc}
\hline & & EA [J] & $\begin{array}{c}\text { U Max } \\
{[\mathbf{m m}]}\end{array}$ & $\begin{array}{c}\text { PCF } \\
{[\mathbf{k N}]}\end{array}$ & $\begin{array}{c}\text { MCF } \\
{[\mathbf{k N}]}\end{array}$ & CLE [-] & SE [-] & TE [-] \\
\hline \multirow{6}{*}{ E } & 1707.6 & 122.96 & 37.50 & 13.89 & 0.370 & 0.615 & 0.228 \\
& AL.-40 & 1708.2 & 124.00 & 36.78 & 13.78 & 0.375 & 0.620 & 0.232 \\
AL.-60 & 1701.8 & 105.61 & 37.24 & 16.11 & 0.433 & 0.528 & 0.228 \\
& AL.-80 & 1702.6 & 101.52 & 37.24 & 16.77 & 0.450 & 0.508 & 0.229 \\
& AL.-100 & 1703.7 & 99.65 & 37.24 & 17.10 & 0.459 & 0.498 & 0.229 \\
& AL.-120 & 1703.2 & 110.47 & 37.24 & 15.42 & 0.414 & 0.552 & 0.229 \\
& AL.-140 & 1703.8 & 109.77 & 37.25 & 15.52 & 0.417 & 0.549 & 0.229 \\
& AL.-160 & 1702.3 & 108.33 & 37.24 & 15.71 & 0.422 & 0.542 & 0.229 \\
& AL.-180 & 1706.1 & 110.30 & 37.05 & 15.47 & 0.418 & 0.552 & 0.230 \\
& AL.-200 & 1703.6 & 106.41 & 37.24 & 16.01 & 0.430 & 0.532 & 0.229 \\
\hline E & 1703.2 & 111.06 & 37.22 & 15.34 & 0.412 & 0.555 & 0.229 \\
AL.-40 & 1698.8 & 98.80 & 37.87 & 17.19 & 0.454 & 0.494 & 0.224 \\
BL.-60 & 1707.7 & 85.42 & 37.89 & 19.99 & 0.528 & 0.427 & 0.225 \\
& AL.-80 & 1712.9 & 81.24 & 37.94 & 21.08 & 0.556 & 0.406 & 0.226 \\
AL.-100 & 1714.9 & 81.34 & 37.96 & 21.08 & 0.555 & 0.407 & 0.226 \\
AL.-120 & 1715.2 & 80.84 & 37.90 & 21.22 & 0.560 & 0.404 & 0.226 \\
AL.-140 & 1714.6 & 81.00 & 37.93 & 21.17 & 0.558 & 0.405 & 0.226 \\
AL.-160 & 1715.2 & 79.24 & 37.97 & 21.64 & 0.570 & 0.396 & 0.226 \\
AL.-180 & 1714.1 & 76.93 & 37.91 & 22.28 & 0.588 & 0.385 & 0.226 \\
AL.-200 & 1715.8 & 74.46 & 38.33 & 23.04 & 0.601 & 0.372 & 0.224 \\
\hline E & 1698.0 & 108.75 & 25.98 & 15.61 & 0.601 & 0.544 & 0.327 \\
AL.-40 & 1701.3 & 111.28 & 26.14 & 15.29 & 0.585 & 0.556 & 0.325 \\
AL.-60 & 1700.3 & 107.62 & 26.30 & 15.80 & 0.601 & 0.538 & 0.323 \\
AL.-80 & 1695.7 & 102.68 & 26.26 & 16.51 & 0.629 & 0.513 & 0.323 \\
AL.-120 & 1693.6 & 101.68 & 26.28 & 16.66 & 0.634 & 0.508 & 0.322 \\
AL.-140 & 1695.0 & 101.20 & 26.30 & 16.74 & 0.636 & 0.506 & 0.322 \\
AL.-160 & 1684.4 & 95.14 & 26.28 & 17.71 & 0.674 & 0.476 & 0.320 \\
AL.-180 & 1689.9 & 91.75 & 26.30 & 18.42 & 0.700 & 0.459 & 0.321 \\
AL.-200 & 1685.4 & 88.31 & 26.26 & 19.09 & 0.727 & 0.442 & 0.321 \\
\hline
\end{tabular}

The results presented in Table 4 show the values of the crush efficiency ratios for the numerical and experimental models verified by the dynamic machine. The values for each specimen are tabulated, and the percentage differences are presented. Among the models tested, the largest discrepancy did not exceed $8 \%$, and for most of the data, the approximate difference was up to $4 \%$. 
Table 4. Difference between numerical and experimental energy absorption indicator.

\begin{tabular}{cccccccc}
\hline & EA [J] & $\begin{array}{c}\text { U Max } \\
{[\mathbf{m m}]}\end{array}$ & $\begin{array}{c}\text { PCF } \\
{[\mathbf{k N}]}\end{array}$ & $\begin{array}{c}\text { MCF } \\
{[\mathbf{k N}]}\end{array}$ & CLE [-] & SE [-] & TE [-] \\
\hline CC32-3-S2 & 1692.36 & 125.50 & 40.234 & 13.485 & 0.3581 & 0.628 & 0.225 \\
C32-3-FEM & 1707.57 & 122.96 & 37.498 & 13.887 & 0.3703 & 0.615 & 0.228 \\
Difference [\%] & 0.90 & 2.02 & 6.80 & 2.98 & 3.41 & 2.02 & 1.31 \\
\hline AL._40_S1 & 1692.36 & 125.50 & 38.734 & 13.485 & 0.3481 & 0.628 & 0.218 \\
AL._40_FEM & 1708.20 & 124.01 & 36.780 & 13.780 & 0.3750 & 0.620 & 0.232 \\
Difference [\%] & 0.94 & 1.19 & 5.05 & 2.19 & 7.72 & 1.20 & 6.20 \\
\hline AL._60_S1 & 1701.92 & 121.93 & 38.182 & 13.958 & 0.3656 & 0.610 & 0.223 \\
AL._60_FEM & 1689.43 & 115.53 & 37.105 & 14.624 & 0.3941 & 0.578 & 0.228 \\
Difference[\%] & 0.73 & 5.25 & 2.82 & 4.77 & 7.81 & 5.25 & 2.15 \\
\hline AL._80_S1 & 1702.47 & 103.24 & 38.954 & 16.490 & 0.4233 & 0.516 & 0.219 \\
AL._80_FEM & 1702.64 & 101.52 & 37.243 & 16.772 & 0.4503 & 0.508 & 0.229 \\
Difference [\%] & 0.01 & 1.67 & 4.39 & 1.71 & 6.38 & 1.67 & 4.61 \\
\hline AL.120_S1 & 1741.28 & 102.67 & 36.654 & 16.027 & 0.4373 & 0.513 & 0.224 \\
AL._120_FEM & 1703.23 & 110.47 & 37.239 & 15.417 & 0.4140 & 0.552 & 0.229 \\
Difference[\%] & 2.19 & 7.60 & 1.60 & 3.80 & 5.32 & 7.60 & 1.88 \\
\hline
\end{tabular}

\section{Conclusions}

This paper presents a numerical and experimental analysis of the crushing of thinwalled aluminum profiles partially filled with aluminum foam. Our research has shown the positive influence of the porous structure on crush efficiency indicators. The interaction of three types of triggers with aluminum foam was studied, where the profiles with a concave-convex initiator, described as BC in Figures 16-18, showed the best alignment. The most effective foam performance was seen for lengths in the $80-120 \mathrm{~mm}$ range, particularly for models with a concave initiator, which was experimentally verified. Numerical and experimental results presented in the form of force-shortening diagrams showed significant agreement in terms of the course and value of maximum shortening. Correspondence between the deformation process in the experiment and that obtained in the numerical FEM simulation was also confirmed by the analysis of high-speed camera imagery (Figures 12 and 13).

Based on the numerical data, one can observe a significant effect of the trigger's configuration (CB vs. BC) on the magnitude of the PCF; however, this value hardly changes at all for different fill lengths with the porous material. Nevertheless, a significant effect on MCF and CLE indices was observed. The increase in their values for individual triggers reached up to $30-50 \%$, proving the positive influence of specific porous fill lengths while keeping the PCF at the same level. Due to the low density and high strain rate in this analysis, the foam filling absorbs the most energy in the last stage of crushing. The filling was too weak to change the value of PCF; nonetheless, as the crushing process progressed, the foam started to absorb increasingly more energy, which is particularly noticeable in Figure 15.

It was noticed in the results that the final value of TE for models with the same crush initiator is practically invariant; this is due to the initial assumptions for the tests performed, where the specimens were subjected to this energy. Since the foam insert absorbs more energy the longer it is in length, it was accompanied by a decreased value of shortening and therefore a lower value of SE. TE, as a product of CLE and SE, remained practically unchanged because as the length of the foam insert increased, CLE increased, and SE decreased simultaneously. Thus, calculating TE when considering a foam insert is not authoritative. 
Author Contributions: Conceptualization, M.R.; Data curation, M.R.; Formal analysis, P.K.; Funding acquisition, K.G.; Methodology, M.R. and M.F.; Supervision, P.K.; Validation, M.R., M.F. and K.G.; Writing—original draft, M.R.; Writing-review \& editing, M.F. and K.G. All authors have read and agreed to the published version of the manuscript.

Funding: Authors Michał Rogala and Mirosław Ferdynus acknowledge funding in the framework of the project Lublin University of Technology-Regional Excellence Initiative, funded by the Polish Ministry of Science and Higher Education (contract no. 030/RID/2018/19). Author Katarzyna Gawdzińska acknowledges funding in the framework of Grant 1/S/KPBMIM/20; Improving the effectiveness of technical systems by changing their structure and using modern materials was granted by the Ministry of Science and Higher Education of Poland.

Institutional Review Board Statement: Not applicable.

Informed Consent Statement: Not applicable.

Data Availability Statement: Data is contained within the article.

Acknowledgments: Lublin University of Technology, Faculty of Mechanical Engineering; Maritime University of Szczecin, Faculty of Marine Engineering; West Pomeranian University of Technology in Szczecin, Faculty of Mechanical Engineering and Mechatronics.

Conflicts of Interest: The authors declare no conflict of interest.

\section{References}

1. Abramowicz, W. Thin-walled structures as impact energy absorbers. Thin-Walled Struct. 2003, 41, 91-107. [CrossRef]

2. Bruski, D.; Burzyński, S.; Chróścielewski, J.; Jamroz, K.; Pachocki, Ł.; Witkowski, W.; Wilde, K. Experimental and numerical analysis of the modified TB32 crash tests of the cable barrier system. Eng. Fail. Anal. 2019, 104, 227-246. [CrossRef]

3. Ferdynus, M.; Kotełko, M.; Urbaniak, M. Crashworthiness performance of thin-walled prismatic tubes with corner dents under axial impact-Numerical and experimental study. Thin-Walled Struct. 2019, 144, 106239. [CrossRef]

4. Alexander, J.M. An approximate analysis of the collapse of thin cylindrical shells under axial loading. Q. J. Mech. Appl. Math. 1960, 13, 10-15. [CrossRef]

5. Abramowicz, W.; Jones, N. Dynamic axial crushing of square tubes. Int. J. Impact Eng. 1984, 2, 263-281. [CrossRef]

6. Abramowicz, W.; Jones, N. Dynamic progressive buckling of circulars and square tubes. Int. J. Impact Eng. 1986, 4, 243-270. [CrossRef]

7. Hanssen, A.G.; Langseth, M.; Hopperstad, O.S. Static crushing of square aluminium extrusions with aluminium foam filler. Int. J. Mech. Sci. 1999, 41, 967-993. [CrossRef]

8. Hanssen, A.G.; Langseth, M.; Hopperstad, O.S. Static and dynamic crushing of square aluminium extrusions with aluminium foam filler. Int. J. Impact Eng. 2000, 24, 347-383. [CrossRef]

9. Kaczyński, P.; Ptak, M.; Gawdzińska, K. Energy absorption of cast metal and composite foams tested in extremely low and high-temperatures. Mater. Des. 2020, 196, 109114. [CrossRef]

10. Hipke, T.; Hohlfeld, J.; Rybandt, S. Functionally Aluminum Foam Composites for Building Industry. Procedia Mater. Sci. 2014, 4 , 133-138. [CrossRef]

11. Gawdzińska, K.; Chybowski, L.; Nabiałek, M.; Szymański, P. A Study of Metal-Ceramic Composite Foams Combustibility. Acta Phys. Pol. A 2019, 135, 304-307. [CrossRef]

12. Gawdzińska, K.; Grabian, J.; Nagolska, D.; Kwiecińska, B. Innovative Multilayer Polymer-glass Composites Reinforced with Metal-ceramic Foam. MATEC Web Conf. 2018, 237. [CrossRef]

13. Duarte, I.; Krstulović-Opara, L.; Dias-de-Oliveira, J.; Vesenjak, M. Axial crush performance of polymer-aluminium alloy hybrid foam filled tubes. Thin-Walled Struct. 2019, 138, 124-136. [CrossRef]

14. Li, Z.; Chen, R.; Lu, F. Comparative analysis of crashworthiness of empty and foam-filled thin-walled tubes. Thin-Walled Struct. 2018. [CrossRef]

15. Song, J.; Xu, S.; Xu, L.; Zhou, J.; Zou, M. Experimental study on the crashworthiness of bio-inspired aluminum foam-filled tubes under axial compression loading. Thin-Walled Struct. 2020, 155, 106937. [CrossRef]

16. Chen, W.; Wierzbicki, T. Relative merits of single-cell, multi-cell and foam-filled thin-walled structures in energy absorption. Thin-Walled Struct. 2001. [CrossRef]

17. Tran, T.N.; Baroutaji, A. Crashworthiness optimal design of multi-cell triangular tubes under axial and oblique impact loading. Eng. Fail. Anal. 2018, 93, 241-256. [CrossRef]

18. Ma, W.; Li, Z.; Xie, S. Crashworthiness analysis of thin-walled bio-inspired multi-cell corrugated tubes under quasi-static axial loading. Eng. Struct. 2020, 204, 110069. [CrossRef]

19. Ying, L.; Zhao, X.; Dai, M.; Zhang, S.; Hu, P. Crashworthiness design of quenched boron steel thin-walled structures with functionally graded strength. Int. J. Impact Eng. 2016, 95, 72-88. [CrossRef] 
20. Ferdynus, M.; Rozylo, P.; Rogala, M. Energy Absorption Capability of Thin-Walled Prismatic Aluminum Tubes with Spherical Indentations. Materials 2020, 13, 4304. [CrossRef]

21. Rogala, M.; Gajewski, J.; Ferdynus, M. Numerical analysis of the thin-walled structure with different trigger locations under axial load. In Proceedings of the IOP Conference Series: Materials Science and Engineering, Kazimierz Dolny, Poland, 21-23 November 2019; Volume 710.

22. Pang, T.; Zheng, G.; Fang, J.; Ruan, D.; Sun, G. Energy absorption mechanism of axially-varying thickness (AVT) multicell thin-walled structures under out-of-plane loading. Eng. Struct. 2019, 196, 109130. [CrossRef]

23. Pirmohammad, S.; Esmaeili Marzdashti, S. Crashworthiness optimization of combined straight-tapered tubes using genetic algorithm and neural networks. Thin-Walled Struct. 2018, 127, 318-332. [CrossRef]

24. Sun, G.; Wang, Z.; Yu, H.; Gong, Z.; Li, Q. Experimental and numerical investigation into the crashworthiness of metal-foamcomposite hybrid structures. Compos. Struct. 2019. [CrossRef]

25. Rahi, A. Controlling energy absorption capacity of combined bitubular tubes under axial loading. Thin-Walled Struct. 2018, 123, 222-231. [CrossRef]

26. Jang, W.Y.; Hsieh, W.Y.; Miao, C.C.; Yen, Y.C. Microstructure and mechanical properties of ALPORAS closed-cell aluminium foam. Mater. Charact. 2015, 107, 228-238. [CrossRef]

27. Ferdynus, M.; Rogala, M. Numerical Crush Analysis of Thin-Walled Aluminium Columns with Square Cross-Section and a Partial Foam Filling. Adv. Sci. Technol. Res. J. 2019, 13, 144-151. [CrossRef]

28. Zhang, Y.; He, N.; Song, X.; Chen, T.; Chen, H. On impacting mechanical behaviors of side fractal structures. Thin-Walled Struct. 2020. [CrossRef]

29. Wang, Y.; Zhai, X.; Ying, W.; Wang, W. Dynamic crushing response of an energy absorption connector with curved plate and aluminum foam as energy absorber. Int. J. Impact Eng. 2018, 121, 119-133. [CrossRef]

30. Mohammadiha, O.; Beheshti, H.; Aboutalebi, F.H. Multi-objective optimisation of functionally graded honeycomb filled crash boxes under oblique impact loading. Int. J. Crashworthiness 2015, 20, 44-59. [CrossRef]

31. Kotełko, M.; Ferdynus, M.; Jankowski, J. Energy absorbing effectiveness-Different approaches. Acta Mech. Autom. 2018, 12, 54-59. [CrossRef]

32. Rogala, M. Neural Networks in Crashworthiness Analysis of Thin-Walled Profile with Foam Filling. Adv. Sci. Technol. Res. J. 2020, 14, 93-99. [CrossRef]

33. Rogala, M.; Gajewski, J.; Ferdynus, M. The Effect of Geometrical Non-Linearity on the Crashworthiness of Thin-Walled Conical Energy-Absorbers. Materials 2020, 13, 4857. [CrossRef]

34. Johnson, G.R.; Cook, W.H. Fracture characteristics of three metals subjected to various strains, strain rates, temperatures and pressures. Eng. Fract. Mech. 1985, 21, 31-48. [CrossRef]

35. Winzer, R.; Glinicka, A. The static and dynamic compressive behaviour of selected aluminium alloys. Eng. Trans. 2011, 59, 85-100.

36. Deshpande, V.S.; Fleck, N.A. Isotropic constitutive models for metallic foams. J. Mech. Phys. Solids 2000, 48, 1253-1283. [CrossRef]

37. Xu, A.; Vodenitcharova, T.; Kabir, K.; Flores-Johnson, E.A.; Hoffman, M. Finite element analysis of indentation of aluminium foam and sandwich panels with aluminium foam core. Mater. Sci. Eng. A 2014, 599, 125-133. [CrossRef]

38. Stręk, A. Methodology for Experimental Investigations of Metal Foams and Their Mechanical Properties. Mech. Control 2012, 31, 90. [CrossRef]

39. Orbulov, I.N.; Szlancsik, A.; Kemény, A.; Kincses, D. Compressive mechanical properties of low-cost, aluminium matrix syntactic foams. Compos. Part A Appl. Sci. Manuf. 2020, 135, 105923. [CrossRef]

40. Zhao, C.Y.; Wu, Z.G. Heat transfer enhancement of high temperature thermal energy storage using metal foams and expanded graphite. Sol. Energy Mater. Sol. Cells 2011, 95, 636-643. [CrossRef]

41. García-Moreno, F. Commercial Applications of Metal Foams: Their Properties and Production. Materials 2016, 9, 85. [CrossRef] [PubMed]

42. Czarnecka-Komorowska, D.; Grześkowiak, K.; Popielarski, P.; Barczewski, M.; Gawdzińska, K.; Popławski, M. Polyethylene Wax Modified by Organoclay Bentonite Used in the Lost-Wax Casting Process: Processing-Structure-Property Relationships. Materials 2020, 13, 2255. [CrossRef]

43. Lehmhus, D.; Weise, J.; Szlancsik, A.; Orbulov, I.N. Fracture Toughness of Hollow Glass Microsphere-Filled Iron Matrix Syntactic Foams. Materials 2020, 13, 2566. [CrossRef] [PubMed] 